\title{
The World Bank's Sanctions System: Using Debarment to Combat Fraud and Corruption in International Development
}

\author{
Pascale Hélène Dubois *, J. David Fielder**, Robert Delonis ${ }^{* * *}$, Frank \\ Fariello $^{* * * *}$ and Kathleen Peters ${ }^{* * * * *}$
}

\begin{abstract}
This chapter presents the main features of the World Bank Group's sanctions system and considers its contribution to global efforts to promote good governance. It first introduces the basic features of the World Bank Group's sanctions system, an administrative law system that has evolved since its inception in 1996. The chapter then briefly reviews the history of that evolution and considers where the system stands today. The chapter also considers the broader international context in which the system was established and continues to operate and concludes by examining some of the lessons learned over the course of the system's 20-year evolution.
\end{abstract}

\footnotetext{
* $\quad$ Pascale Hélène Dubois, Vice President, World Bank Group Integrity Vice Presidency, pdubois@worldbank.org.

** J. David Fielder, Manager, World Bank Group Integrity Vice Presidency, jfielder@world bank.org.

*** Robert Delonis, Senior Litigation Specialist, World Bank Group Integrity Vice Presidency, rdelonis@worldbank.org.

**** Frank Fariello, Lead Counsel, World Bank Legal Vice Presidency, ffariello@worldbank .org.

****** Kathleen Peters, Senior Legal Consultant, World Bank Group Integrity Vice Presidency, kpetersı@worldbank.org.

The authors wish to thank Sheherezade C. Malik, Consultant, World Bank Legal Vice Presidency; Corinne Champilou, Legal Analyst, World Bank Group Integrity Vice Presidency; Lisa Miller, Integrity Compliance Officer, World Bank Group Integrity Vice Presidency; and Arjun Ponnambalam, Senior Consultant, World Bank Group Integrity Vice Presidency, for their invaluable assistance and contributions in the preparation of this article.
} 


\section{A Short History of Anti-corruption Developments in The International Context}

The World Bank Group's (WBG $)^{1}$ sanctions system grew out of its operational procurement framework, and its evolution has been shaped by the broader international fight against corruption. It would seem now intuitively obvious that the ability to exclude corrupt actors from WBG-financed development activities would be a logical, and perhaps essential, measure to ensure the proper use of WBG funds. But the sanctions system was not an original, or even early, part of the WBG's fiduciary toolkit.

The Articles of Agreement establishing the International Bank for Reconstruction and Development (IBRD) - which, together with the International Development Association, is referred to as the "World Bank" (Bank)—date from 1945, when the Bank was created under the Bretton Woods Agreement to help rebuild Europe after the Second World War. ${ }^{2}$ The WвG sanctions system, on the other hand, dates only from 1996 , nearly 50 years later. ${ }^{3}$

What brought about this change in approach? In part, the establishment of the sanctions system was a reaction to contemporaneous changes in anticorruption laws, norms and practices at the national level. The first legal instrument to support this change, the US Foreign Corrupt Practices Act (FCPA), had been enacted some 20 years prior, in $1977 .{ }^{4}$ But it was not until the 1990s and 2000 s that the FCPA began to be robustly enforced. ${ }^{5}$ Early enforcement

1 The WBg consists of the International Bank for Reconstruction and Development (IBRD), International Development Association (IDA), International Finance Corporation (IFC) and Multilateral Investment Guarantee Agency (MIGA). The International Centre for the Settlement of Investment Disputes (ICSID) is also a part of the WBG, but its operations are not covered by the sanctions system.

2 International Bank for Reconstruction and Development Articles of Agreement (IBRD Articles of Agreement) (as amended effective 27 June 2012) arts I \& IX, s 3.

3 World Bank, "World Bank Sanctions Regime: An Overview" <http://siteresources.worldbank .org/EXTOFFEVASUS/Resources/Overview-SecM2010-0543.pdf> accessed 19 April 2018; see Dick Thornburgh, Ronald Gainer \& Cuyler Walker, "Report Concerning the Debarment Processes of the World Bank" (14 August 2002) ("Thornburgh Report") 10-12.

4 Foreign Corrupt Practices Act of 1977 (as amended 15 U.s.c. ss. 78dd-1, et seq).

5 See Stanford Law School, "Foreign Corrupt Practices Act Clearinghouse, A Collaboration with Sullivan \& Cromwell LLP: DOJ and SEC Enforcement Actions" <http://fcpa.stanford .edu/statistics-analytics.html > accessed 17 January 2018 (providing a chart of the FCPA's enforcement history from 1977 to the present); see also Tov Krever, "Curbing Corruption? The Efficacy of the Foreign Corrupt Practices Act” (2007) 33 NC J Intl L \& Com Reg 83, 93 (stating that in its first two decades, FCPA enforcement was "sporadic" at best and confined to high profile cases); Russell Gold \& David Crawford, "US, Other Nations Step Up Bribery Battle" Wall Street Journal (New York, 12 September 2008) B1 (noting that the FCPA's early years were 
efforts were tempered by the US Department of Justice's (DOJ) concerns that strong enforcement of the Act could potentially harm US relations with its allies. ${ }^{6}$ Since the early 2000 , acknowledging that corruption "is a hugely destabilizing force," the DOJ has moved toward more vigorous FCPA enforcement, and has increased the severity of the penalties imposed for violations. ${ }^{7}$ Since the mid-200os, enforcement by the US Securities and Exchange Commission (SEC) has also become more muscular, with the creation of a specialized unit within its Enforcement Division that investigates potential FCPA violations. ${ }^{8}$

A change in attitude on the part of firms, governments and public opinion helped accelerate a move towards the criminalization of foreign bribery. Before this change, it had been generally accepted -indeed often expected-for firms to pay bribes to secure public contracts abroad. In fact, in many countries bribes were a tax-deductible business expense. ${ }^{9}$

In 1996, the Member States of the Organization of American States (OAS) adopted the Inter-American Convention Against Corruption, which was the first international anti-corruption convention..$^{10}$ The following year, the Organization for Economic Cooperation and Development (OECD) concluded the landmark Convention on Combating Bribery of Foreign Public Officials in International Business Transactions, commonly known as the "OECD Anti-Bribery Convention."11 The oECD Anti-Bribery Convention advanced

characterized by "long periods of little activity and few prosecutions," experiencing a drastic increase in activity since the early 2000 ).

6 W.L. Larson, "Effective Enforcement of the Foreign Corrupt Practices Act" (1980) $3^{2}$ Stan L $\operatorname{Rev} 561, \mathrm{n} 1$.

"Mendelsohn Says Criminal Bribery Prosecutions Doubled in 2007" (16 September 2008) 22 Corporate Crime Reporter 36(1) <www.corporatecrimereporter.com/mendelsohnog16o8. $\mathrm{htm}>$ accessed 18 January 2018; see Gold \& Crawford (n 5).

8 Steven R. Peikin, "Reflections on the Past, Present, and Future of the SEC's Enforcement of the Foreign Corrupt Practices Act" (US Securities and Exchange Commission, 9 November 2017) <www.sec.gov/news/speech/speech-peikin-2017-11-09\#_ednref6> accessed 18 January 2018 (noting that since the unit's creation, the SEC has initiated 106 FCPA-related actions against 101 entities and 38 individuals).

9 See Martine Milliet-Einbinder, "Writing Off Tax Deductibility" (oEcD Observer, April 200o), <http://oecdobserver.org/news/archivestory.php/aid/245/Writing_off_tax_deduct ibility_html> accessed 18 January 2018 (noting that in the late 1990s, in countries such as Australia, Austria, Belgium, France, Germany, Luxembourg, The Netherlands, Portugal, New Zealand and Switzerland, bribes to foreign public officials were considered taxdeductible expenses, sometimes with the caveat that the recipient's identity be disclosed). Organization of American States, Inter-American Convention Against Corruption (B-58) (adopted at the third plenary session of Member States, 29 March 1996).

11 Organization for Economic Cooperation and Development, Convention on Combating Bribery of Foreign Public Officials in International Business Transactions (oECD 
international anti-corruption enforcement across regions and now has 43 States Parties across all parts of the world. ${ }^{12}$

The 1990s also saw more open recognition and discussion of corruption's harm to development outcomes-in economic literature and beyond..$^{13}$ This emerging consensus helped prompt the 1993 foundation of Transparency International by Peter Eigen, a former Bank staff member. ${ }^{14}$ It also helped international financial institutions (IFIs) to understand that corruption is more than just a minor "transaction cost," or a political issue that they were prohibited from tackling. ${ }^{15}$ The now-famous speech by WвG President James

Anti-Bribery Convention) (adopted by the Negotiating Conference 21 November 1997, opened for signature 17 December 1997).

Ibid; OECD, "OECD Anti-Bribery Convention Ratification Status as of May 2017" <www .oecd.org/daf/anti-bribery/WGBRatificationStatus.pdf> accessed 17 January 2018.

13 See, for example, World Bank Group, "World Development Report 1997: The State in a Changing World" (1997) 99-109; Cheryl Gray \& Daniel Kaufmann, "Corruption and Development” (March 1998) Finance \& Development 7. More recently, the World Bank's entire 2017 World Development Report was dedicated to governance issues. World Bank Group, "World Development Report 2017: Governance and the Law" (2017).

14 Transparency International, "FAQS on Transparency International: Why Was Transparency International Founded? \& How Was Transparency International Founded?" <www .transparency.org/whoweare/organisation/faqs_on_transparency_international/9> accessed 17 January 2018.

15 The IвRD's Articles of Agreement prohibit it from interfering in the "political affairs of any [of its] member[s]," and from being "influenced in [its] decisions by the political character of a member." IBRD Articles of Agreement (n 2) art IV, s 1o. Further, the articles require the Bank's loan proceeds to be used "without regard to political or other non-economic influences or considerations." ibid art III, s 5(b). This "political prohibition" has dictated the Bank's policy considerations and the way it conducts its operations. While the Bank was to avoid "complex political considerations," as it developed "the operational experience "to deal with a large number of governance and institutional issues which have direct relevance to its development mandate, ... and corruption had become a major issue of development policy, the Bank could take action in relation to the fight against corruption." Hassane Cissé, "Should the Political Prohibition in Charters of International Financial Institutions Be Revisited? A Case of the World Bank" in Hassane Cissé, Daniel D. Bradlow \& Benedict Kingsbury (eds), International Financial Institutions and Global Legal Governance (3 World Bank L Rev 59, 78-79, 2012) (quoting Ibrahim F.I. Shihata, "Corruption: A General Review with an Emphasis on the Role of the World Bank" (1997) 15 Dick J Intl L 451, 475-476). Further, the fiduciary duty of multilateral development banks (MDBs), such as the World Bank, to their stakeholders to ensure proper use of stakeholder funds "underlies sanctions, which operate as a key disincentive against the misuse of мDв funds." Stephen S. Zimmermann \& Frank A. Fariello, Jr., "Coordinating the Fight against Fraud and Corruption: Agreement on CrossDebarment among Multilateral Development Banks" in Cissé, Bradlow \& Kingsbury (n 15) 189-190. 
Wolfensohn in 1996, in which he described corruption as a cancer, ${ }^{16}$ was a landmark in this change in IFIs' approach to corruption.

There have been numerous other milestones in the 20 years since. In 2005, the United Nations (UN) Convention Against Corruption (UNCAC) entered into force. ${ }^{17} \mathrm{UNCAC}$ has perhaps been the most far-reaching international anti-corruption convention, as it requires its 183 States Parties to, among other things, pass domestic legislation criminalizing the bribery of foreign public officials and the officials of public international organizations. ${ }^{18}$

Following the OECD Anti-Bribery Convention and UNCAC, and accelerating in recent years, many countries passed new or strengthened anti-corruption laws. These include the 1999 Canadian Corruption of Foreign Public Officials Act, ${ }^{19}$ the 2010 United Kingdom Bribery Act, ${ }^{20}$ China's 2011 and 2015 antibribery amendments to its Criminal Law, ${ }^{21}$ India's 2013 Lokpal and Lokayuktas Act to combat corruption, ${ }^{22}$ the 2014 Brazil Clean Company Act ${ }^{23}$ and France's 2016 Law on Transparency, the Fight Against Corruption and Modernization of Economic Life, commonly called the "Sapin II" Act. ${ }^{24}$

Other important milestones were not driven by governments or international organizations. For example, the Panama Papers, and the more recent Paradise Papers, were disclosed and analyzed by the International Consortium of Investigative Journalists, and have helped to put a global spotlight on the links between illicit financial flows and corruption. ${ }^{25}$ The corruption and

16 James Wolfensohn, "People and Development" (Address to the Board of Governors at the Annual Meetings of the World Bank and the International Monetary Fund, 1 October 1996) <http://documents.worldbank.org/curated/en/135801467993234363/pdf/99712-WPBox393210B-PUBLIC-1996-10-01-People-and-Development.pdf> accessed 18 January 2018.

17 United Nations Convention Against Corruption (UNCAC), UNGA Res 58/4 (adopted $3^{1}$ October 2003, entered into force 15 December 2005).

18 Ibid art 16; UNODC, "UNCAC Signature and Ratification Status" < www.unodc.org/unodc/ en/corruption/ratification-status.html $>$ accessed 17 January 2018.

19 Corruption of Foreign Public Officials Act, s.c. 1998, c 34.

$20 \quad 2010$ United Kingdom Bribery Act c.23.

21 Criminal Law of the People's Republic of China, pt 2, Ch viII (Crimes of Embezzlement and Bribery) (adopted at the Second Session of the Fifth National People's Congress on 1 July 1979, amended 25 February 2011); and Criminal Law of the People's Republic of China Amendment 9 (promulgated 29 Aug. 2015).

22 The Lokpal and Lokayuktas Act (2013) No 1 of 2014, India Code (rev 29 July 2016).

23 Law No 12.846 (1 August 2013). The Act took effect in January 2014, and thus is commonly referred to as a 2014 statute.

24 Law No 2016-1691 (9 December 2016).

25 International Consortium of Investigative Journalists (ICIJ), "The Panama Papers" $<$ https://panamapapers.icij.org/> accessed 17 January 2018; ICIJ, "The Paradise Papers" $<$ www.icij.org/investigations/paradise-papers/> accessed 17 January 2018. 
money laundering issues raised by these disclosures have been taken up by international policy-making bodies, such as the Financial Action Task Force ${ }^{26}$ and the G2o Anti-Corruption Working Group, ${ }^{27}$ which are exerting an increasing influence on this global agenda.

The WBG's anti-corruption work matured alongside these international developments and alongside the partners who lead them. Diagnostic work, institutional capacity building and global initiatives are at the forefront of the Bank's anti-corruption efforts. The Bank's diagnostic work includes an array of analytical tools to measure corruption nationally and globally. The Worldwide Governance Indicators permit cross-country comparisons regarding corruption and governance indicators and provide data on specific issues, such as the frequency of bribe payments and the complexity of regulatory environments. ${ }^{28}$ Nationally, the Bank analyzes corruption risks for particular sectors and performs survey-based diagnostic work. ${ }^{29}$ The Bank also identifies and works to address corruption risks at the country and project levels, through tools like Country Policy and Institutional Assessments (CPIAs), the Systematic Operations Risk-Rating Tool (sORT) and Anti-Corruption Action Plans. ${ }^{30}$

The Bank's institutional-capacity-building work involves support for client countries in the creation, reform and development of institutions such as domestic anti-corruption agencies, laws and regulatory systems, including in corruption-affected areas like procurement and customs. ${ }^{31}$ Further, in 2007 the WBG and the United Nations Office on Drugs and Crime (UNODC) jointly formed the Stolen Asset Recovery Initiative (StAR), "to end safe havens for corrupt funds" by working with developing countries "to prevent the laundering of

26 Financial Action Task Force, "Who We Are" < www.fatf-gafi.org/about/> accessed 17 January 2018.

27 G20 Argentina 2018, "Work Streams: Anti-Corruption" <www.g20.org/en/g20-argentina/ thematic-areas/anti-corruption $>$ accessed 17 January 2018.

28 World Bank, "Worldwide Governance Indicators: Control of Corruption" <http://info .worldbank.org/governance/wgi/\#doc> accessed 5 February 2018.

29 Ibid.

3o See World Bank, "Fast Track Brief: The World Bank's Country Policy and Institutional Assessment-An Evaluation” (30 June 2009); World Bank, "DataBank: Worldwide Governance Indicators" <info.worldbank.org/governance/wgi/\#doc> accessed 5 February 2018; World Bank, "Guidance Note: Systematic Operations Risk-Rating Tool (sorT)" (25 June 2014) <pubdocs.worldbank.org/en/972311473706061935/SORTGuidanceNote2014. pdf $>$ accessed 5 February 2018; World Bank Group, "Transparency, Good Governance and Anti-Corruption Mechanisms" <http://ppp.worldbank.org/public-private-partnership/ overview/practical-tools/good-governance-anticorruption\#anticorruption> accessed 5 February 2018.

31 See, for example, World Bank, "Combating Corruption" (26 September 2017) <www.worldbank.org/en/topic/governance/brief/anti-corruption>accessed 5 February 2018. 
the proceeds of corruption and to facilitate more systematic and timely return of stolen assets." ${ }^{32}$ The WBG's global initiatives draw on international partnerships, notably through civil society engagement and transparency movements, to implement anti-corruption programs..$^{33}$ Examples include the Extractive Industries Transparency Initiative (EITI), the Construction Sector Transparency Initiative (CoST) and Open Contracting. ${ }^{34}$

Other multilateral and regional development banks have been key partners in this journey ${ }^{35}$-in line with the 2006 Joint International Financial Institution Anti-Corruption Task Force (IFI Task Force), in which involved multilateral development banks (MDBs) agreed to harmonize their approaches to combatting corruption. ${ }^{36}$ As a result, their investigative and sanctions systems all share many core elements, among the most important of which includes harmonizing the definitions for the then four sanctionable practices (i.e., "corrupt," "fraudulent," "coercive" and "collusive" practices): ${ }^{37}$

32 World Bank \& UNODC, "Stolen Asset Recovery Initiative (StAR)" < https://star.worldbank. org/star/> accessed 19 January 2018.

33 See World Bank, "Combating Corruption" (n 31 ).

34 Extractive Industries Transparency Initiative, "The Global Standard for the Good Governance of Oil, Gas and Mineral Resources" < www.eiti.org > accessed 5 February 2018; Construction Sector Transparency Initiative, "Home" <www.constructiontransparency.org/ home > accessed 5 February 2018; Open Contracting Partnership, "About" <www.opencontracting.org/about/> accessed 5 February 2018.

35 The International Monetary Fund (IMF) was also engaged in this initiative, noting that though it encourages and supports anti-corruption efforts in both project lending and dealings with private entities, "[u]nlike the other member institutions, the IMF does not engage in project lending or lending to the private sector. It maintains procedures tailored to the circumstances of the IMF to deal with potential issues of staff misconduct and safeguard the use of Fund resources." "International Financial Institutions Anti-Corruption Task Force, Uniform Framework for Preventing and Combating Fraud and Corruption" (IFI Task Force) (September 2006) 1.

36 Ibid. In addition to the WBG, the IFIs involved in this IFI Task Force were the African Development Bank, the Asian Development Bank, the European Bank for Reconstruction and Development, the Inter-American Development Bank, the European Investment Bank and the IMF.

37 See Zimmermann \& Fariello (n 15) 191 (noting that each MDв established its own "integrity" office to investigate corruption allegations, created its own adjudicative mechanism to assess the merits of these allegations and ultimately settled on debarment as the most likely sanction to be imposed). Eventually, an automatic cross-debarment regime was also agreed upon to improve the deterrent effect of sanctions by individual MDBs and to compound the effects of a public debarment on an entity by foreclosing the possibility of that entity being awarded contracts with other MDBs. ibid 196-198. Further, for a more in-depth discussion on the Bank's sanctions process and the impact of general legal principles on this sanctions system, see Pascale Hélène Dubois \& Aileen Elizabeth Nowlan, 
- The Asian Development Bank (АDв), which passed its first Anticorruption Policy in 1998, ${ }^{38}$ has an Office of Anti-Corruption and Integrity (OAI) that receives allegations of fraud and corruption by ADB staff or in ABDfinanced projects. ${ }^{39}$ OAI then reviews these complaints to ensure that they meet the requirements to proceed with a full-fledged investigation. ${ }^{40}$ The investigative process varies depending upon whether the subject is a staff member or a third party (for example, consultants, bidders, contractors or suppliers). For staff-member allegations, OAI reports its findings to the Budget, Personnel and Management Systems Department, which reviews OAI's report and conducts administrative proceedings when appropriate. ${ }^{41}$ For allegations involving third parties, investigative subjects may submit responses to allegations to the Integrity Oversight Committee (IOC). ${ }^{42}$ The IOc then determines the credibility of the responses and decides whether to impose any remedial actions or sanctions. ${ }^{43}$ Sanctions may be appealed to the Sanctions Appeals Committee. ${ }^{44}$ In addition to conducting investigations, OAI also engages in project procurement-related reviews, advises on integrity due diligence to minimize risks in its private sector projects and disseminates information on its anti-corruption policy. 45

- The Inter-American Development Bank (IADB) approved its first sanctions framework in $2001 .{ }^{46}$ Its current Sanctions System consists of investigation and adjudication phases. ${ }^{47}$ The Office of Institutional Integrity (OII), an

"Global Administrative Law and the Legitimacy of Sanctions Regimes in International Law" (2010) 36 Yale J Intl L 15 .

38 Asian Development Bank (ADB), Office of the Auditor General, "Annual Report on the Major Activities of the Anticorruption Unit 2003" (January 2004) pt 1, para 1.

39 АDв, "Office of Anti-Corruption and Integrity" < www.adb.org/site/integrity/overview> accessed 19 January 2018.

ADB, "Anti-Corruption and Integrity: Investigations" < www.adb.org/site/integrity/investigations $>$ accessed 19 January 2018.

41 ADB, "Process for Dealing with Allegations of Integrity Violations by AD B Staff" < $w w w$. adb.org/sites/default/files/page/16129o/process-for-dealing-with-allegations-adb-staff. pdf> accessed 19 January 2018.

42 ADB, "Process for Dealing with Allegations of Integrity Violations Involving Bidders, Consultants, Contractors, Suppliers, or Other Third Parties in ADB-Related Activities" <www. adb.org/sites/default/files/page/16129o/process-for-dealing-with-allegations-externalparties.pdf $>$ accessed 19 January 2018.

43 Ibid.

44 Ibid.

45 AD B, "Office of Anti-Corruption and Integrity" (n 39).

46 Inter-American Development Bank (IDB), “ІDв Sanctions System" <https://www.iadb. org/en/about-us/idb-sanctions-system\%2C8619.html > accessed 22 January 2018.

Ibid. 
independent advisory office, investigates allegations of prohibited practices. ${ }^{48}$ If oII concludes that a prohibited practice has occurred, a two-step adjudication process commences, with a Sanctions Officer issuing a determination that can be appealed to a Sanctions Committee. ${ }^{49}$ Specifically, if the Sanctions Officer determines that the subject engaged in a prohibited practice, it notifies the subject of the commencement of sanctions proceedings and gives the subject an opportunity to respond..$^{50}$ The Sanctions Officer then evaluates the sufficiency of all the evidence and issues a "determination" of whether sanctions are appropriate. ${ }^{51}$ The Sanctions Officer's determination can be appealed to the Sanctions Committee, which independently reviews the evidence and is not bound by the Sanctions Officer's decision. ${ }^{52}$

- The European Bank for Reconstruction and Development's (EBRD) investigative work dates back to the early 2000s..$^{53}$ It presently has an Office of the Chief Compliance Officer (OCCO) that investigates allegations of fraud, corruption and other misconduct by EBRD staff or under EBRD-financed projects. ${ }^{54}$ If misconduct is discovered under an EBRD-financed project, EBRD also follows a two-tier enforcement process involving an Enforcement Commissioner (first tier) and an Enforcement Committee (second tier) to decide and impose the appropriate sanction. ${ }^{55}$

- The European Investment Bank's (eIB's) Anti-Fraud Policy and related Investigation Procedures, published in 2013 and based upon the IFI Task Force's Uniform Framework, sets forth EIB's policy in preventing and deterring corruption, fraud, collusion, coercion, obstruction, money laundering and terrorist financing (jointly, Prohibited Conduct). ${ }^{56}$ At present, the EIB

48 Ibid.

49 Ibid.

50 Ibid.

51 Ibid.

52 Ibid.

53 Specifically, its Office of the Chief Compliance Officer (occo) has investigated staff misconduct since 2002 and misconduct under EBRD-financed procurements since 2005 . European Bank for Reconstruction and Development (EBRD), "EBRD Anti-Corruption Report" (November 2006) 17 \& 19.

54 EBRD, "Integrity and Compliance" <www.ebrd.com/integrity-and-compliance.html> accessed 18 January 2018.

55 EBRD, "Enforcement Policy and Procedures" POL/2017/o1 (4 October 2017) s III.

56 European Investment Bank (ЕІв), "Policy on Preventing and Deterring Prohibited Conduct in European Investment Bank Activities" (“ЕІв Anti-Fraud Policy”) (17 September 2013). For a predecessor policy, see Егв, "ЕІв Guidelines on Fighting Corruption, Fraud, Money Laundering and the Financing of Terrorism” (2 May 2006). 
Inspectorate General has a Fraud Investigations Division (IG/IN) that investigates Prohibited Conduct in EIB-financed projects and activities. ${ }^{57}$ IG/IN also conducts proactive integrity reviews, training and awareness-raising activities and integrity policy work, ${ }^{58}$ and cooperates closely with the European Anti-Fraud Office (OLAF). ${ }^{59}$ EIB also recently adopted an Exclusions Policy under which it can debar firms that engaged in Prohibited Conduct. ${ }^{60}$

- The African Development Bank (AfDB) Office of Integrity and AntiCorruption (PIAC, formerly called IACD) was founded in $2006,{ }^{61}$ and aims to deter, prevent and investigate sanctionable practices or staff misconduct affecting the AfDB. ${ }^{62}$ PIAC's Investigations Division conducts administrative fact-finding inquiries into allegations of misconduct and refers findings of misconduct involving AfDB staff to the AfDB President for action. ${ }^{63}$ Sanctionable practices occurring under AfDB-financed projects are addressed through an independent, two-tier decision-making system involving an Independent Sanctions Commissioner and Sanctions Appeals Board. ${ }^{64}$ In addition to its Investigations Division, PIAC also has an Integrity and Prevention Division that holds trainings, conducts outreach and develops due diligence and risk assessment tools. ${ }^{65}$

- Most recently, the Asian Infrastructure Investment Bank (AIIB) has appointed Investigations Officers (reporting to the Managing Director of the Compliance, Effectiveness and Integrity Unit) to investigate suspected Prohibited Practices (as defined by AIIB). ${ }^{66}$ If a party has engaged in a Prohibited Practice, АIı B utilizes a two-tier sanctions system, involving a Sanctions

57 EIB, "Investigating Prohibited Conduct" < www.eib.org/about/accountability/anti-fraud/ index.htm > accessed 18 January 2018.

58 Ibid.

59 "ЕІв Anti-Fraud Policy" (n 56 ) 2, s II.

6o EIB, "Exclusion Policy" (19 February 2018).

61 African Development Bank (AfDB), Integrity and Anti-Corruption Department, "Integrity and Anti-Corruption Progress Report 2009-2010" (2011) 14; AfDB, "Integrity and AntiCorruption" <www.afdb.org/en/about-us/organisational-structure/integrity-and-anti -corruption/> accessed 17 January 2018.

62 AfDB, "Integrity and Anti-Corruption."

63 Ibid.

64 AfDB, "Integrity and Anti-Corruption: Sanctions" < www.afdb.org/en/about-us/organisa tional-structure/integrity-and-anti-corruption/sanctions/> accessed 17 January 2018.

65 AfDB, "Integrity and Anti-Corruption: Divisions" < www.afdb.org/en/about-us/organisa tional-structure/integrity-and-anti-corruption/divisions/> accessed 17 January 2018.

66 Asian Infrastructure Investment Bank, "Policy on Prohibited Practices" (8 December 2016) 5 , s 3.4. 
Officer and Sanctions Panel, to impose an appropriate sanction. ${ }^{67}$ The AIIB also follows the cross-debarment decisions of other MDBs. ${ }^{68}$

The International Monetary Fund (IMF) has recently raised the profile of its anti-corruption efforts. As recently as September 2017, Christine Lagarde, the IM F's Managing Director, reinforced the IMF's commitment to tackling corruption, noting that " $[\mathrm{t}]$ he Board agreed that [member countries] would benefit from an increase in granular policy advice, and a candid, even-handed assessment of the economic impact of corruption." 69 Guided by its understanding that "systemic corruption can undermine prospects for delivering sustainable and inclusive growth," in the same year, the IM F published a report detailing its anti-corruption efforts in its economic reviews and IMF-supported programs in its member countries. ${ }^{70}$

These institutional developments have been accompanied by a sea change in popular attitudes, especially among young people. According to a 2017 World Economic Forum youth survey, the two subjects of greatest concern for young people today are climate change and corruption. ${ }^{71}$ They no longer wearily accept corruption as an inevitable part of life in many countries, as their parents once did.

In parallel, this period has seen an international movement towards incentivizing "clean business practices" in the private sector, as reflected in the use of compliance programs and monitors in US Department of Justice Deferred or Non-Prosecution Agreements. ${ }^{72}$ The WBG sanctions system has itself contributed to the wider adoption of "private sector integrity compliance" frameworks through its use of debarments with conditional release and conditional non-debarments, both of which require sanctioned firms to enhance their compliance programs. ${ }^{73}$

\footnotetext{
67 Ibid 6-12, ss IV-VII.

68 Ibid 17-18, s XII.

69 Christine Lagarde, IMF Managing Director, "Addressing Corruption with Clarity" (Brookings Institution, Washington, DC, 18 September 2017) <https://www.imf.org/en/News/Ar ticles/2017/og/18/spog1817-addressing-corruption-with-clarity> accessed 26 January 2018.

70 IMF, "IMF Policy Paper: The Role of the Fund in Governance Issues-Review of the Guidance Note-Preliminary Considerations" (August 2017).

71 World Economic Forum, "Global Shapers Survey" (2017) $15<$ www.shaperssurvey2017.org/ static/data/WEF_GSC_Annual_Survey_2017.pdf> accessed 22 January 2018.

72 The first official guidance regarding the use of such monitors was issued in 2008. Memorandum from Craig Morford, Acting Attorney General, to Heads of Department Components, United States Attorneys, re: Selection and Use of Monitors in Deferred Prosecution Agreements and Non-Prosecution Agreements with Corporations (7 March 2008).

73 World Bank, "Bank Procedure: Sanctions Proceedings and Settlements in Bank Financed Projects" ("World Bank Sanctions Procedures") (issued 28 June 2016) s III(A)(9.01)(b) \&
} 
Although often referred to with the shorthand "fraud and corruption," the wB G sanctions five distinct forms of misconduct: fraud, corruption, collusion, coercion and obstruction of a WBG Integrity Vice Presidency (INT) investigation. ${ }^{74}$ In 2006, the WBG revised its definitions of fraudulent, corrupt, collusive and coercive practices to clarify and harmonize them with the definitions used by the AfDB, ADB, ЕвRD, ЕIв and IADB. ${ }^{75}$

The WBG's sanctions system is designed both to protect the integrity of WBG development projects and to deter future wrongdoing, while at the same time incentivizing the remediation and rehabilitation of sanctioned entities. ${ }^{76}$ Among other measures, the sanctions system provides for the suspension and debarment of firms and individuals found to have engaged in sanctionable practices when competing for, or executing, Bank-financed contracts.

The sanctions system finds its legal basis in the Bank's "fiduciary duty" to take appropriate measures to ensure that its funds-the WBG committed more than USD61 billion in loans, grants, equity investments and guarantees in $2017^{77}$ - are used for their intended purposes, with due attention to considerations of economy and efficiency. ${ }^{78}$ This duty is set out in the Bank's Articles of Agreement.

Further, the sanctions system flows naturally from the Bank's role as a development institution. Fraud and corruption, and the poor governance they both symptomize and help perpetuate, harm development at the national and project levels. At the national level, corruption acts as a drag on investment and economic growth. A recent IMF research paper estimated that bribery alone could cost between USD1.5 and 2 trillion annually, or roughly two percent of global GDP; and observed that corruption adversely affects financial stability, public and private investment, human capital formation, total factor

(d); World Bank Group Integrity Vice Presidency, "2016 Annual Update” (2016) (INT, "2016 Annual Update"); World Bank Group Integrity Vice Presidency, "2017 Annual Update” (2017) (INT, "2017 Annual Update") 29-30. For a further discussion of the pro-competitive objectives of the WBG sanctions system, see Bart Stevens \& Robert Delonis, "Leveling the Playing Field: A Race to the Top" (2013) 5 World Bank L Rev 399. "World Bank Sanctions Procedures" (n 73) s II (r).

75 IFI Task Force (n 35) 1; Anne-Marie Leroy \& Frank Fariello, "World Bank Study: The World Bank Group Sanctions Process and Its Recent Reforms" (2012) 11.

76 World Bank Group, "wвg Policy: Sanctions for Fraud and Corruption" (issued 13 June 2016) S III(A); see Leroy \& Fariello (n 75) (articulating the early history of the World Bank Sanctions System and the relevant reforms that have since followed).

77 World Bank, "Annual Report" (2017) 3 (regarding WBg fiscal year 2017).

$78 \quad$ IBRD Articles of Agreement (n 2) art III, s (5)(b). 
productivity, taxation and revenue collection (and thus government spending) and more. ${ }^{79}$ At the project level, INT investigations have found corruption schemes that involved millions of dollars in project funds; corruption schemes hidden by false reports of project progress; and bribes funded by false, inflated invoices. ${ }^{80}$ All of this wastage of project funds directly harms the development impact of these projects.

The WBG sanctions system was the first of its kind among international organizations and it has evolved significantly since its inception in 1996. The development of the WBG's sanctions system reflects a continued dedication to the core pillars of good governance, including transparency, stakeholder participation, the rule of law and accountability, coupled with a focus on providing an effective and efficient sanctions system to ensure that the institution's funds are used for their intended purposes.

Under its original configuration, decisions to investigate an allegation, and to pursue an administrative sanctions case, involved members of the Bank's legal department (including the General Counsel), senior Bank audit and procurement officials and a Managing Director. ${ }^{81}$ An internal Sanctions Committee heard every case, regardless of whether it was contested, and was comprised of still more of the Bank's senior-most staff: two Managing Directors, the General Counsel and two Vice Presidents. ${ }^{82}$ The final sanctioning decision was made by the President of the Bank, based upon the Sanctions Committee's recommendation. ${ }^{83}$

Between this system's creation in 1996 and its review in 2002, only 18 cases were concluded, resulting in the debarment of 74 entities. ${ }^{84}$ With time, the sanctions system evolved to respond to the operational and due process considerations prompted by this initial incarnation.

In 2007, following the issuance of a seminal report of recommendations by former US Attorney General and UN Under-Secretary General Dick Thornburgh, ${ }^{85}$ the system was reconfigured as a more formal two-tiered process, which is detailed below. The introduction of a two-tier system was driven

\footnotetext{
79 IMF, “IMF Staff Discussion Note, Corruption: Costs and Mitigating Strategies” (SDN/16/05, 2016) 5-11.

8o World Bank Group Integrity Vice Presidency, "Annual Update Fiscal Year 2015" (2015) 5-8; INT, "2016 Annual Update” (n 73) 7-8.

81 "Thornburgh Report" (n 3 ) 13-14.

82 Ibid $14-15$.

83 Ibid 19 .

84 Ibid 20.

85 Ibid.
} 
by an operational need to expedite case resolutions, ${ }^{86}$ and to address risks arising during case pendency, while also enhancing due process. Among other things, the Bank understood that the decision to publicly list sanctioned entities and individuals could significantly impact those parties. The two-tiered process sought to continue to ensure that every sanctions decision was based on sufficient evidence and subject to independent adjudication, while also allowing for expeditious resolution of uncontested cases.

\section{The Investigative Process}

Typically, a sanctions case starts with an allegation of one or more of the five sanctionable practices.

The Bank's Anti-Corruption Guidelines, ${ }^{87}$ which are incorporated in legal agreements with borrowing countries, and the Bank's Procurement Regulations $^{88}$ and related bidding documents ${ }^{89}$ all reference the Bank's definitions of sanctionable practices, as well as the consequences of engaging in them. ${ }^{90}$ INT applies these definitions in its work, using those stated in the relevant procurement or contract documents, or else those stated in the underlying legal agreements for the project. ${ }^{91}$

86 For a detailed discussion on the reasons that led to the creation of a two-tiered sanctions system, see the Thornburgh Report (n 3). The Report noted, for example, that problems such as the spike in caseload and their complexity, the increasingly dilatory and aggressive tactics displayed by respondents and the average length of time between case referral and final disposition would make it difficult for the Bank to adjudicate matters that presented credible evidence of corrupt behavior. It reasoned that a two-tiered system would permit the Bank to dispose of certain cases without necessitating a full hearing before the Sanctions Committee and would allow for the temporary suspension of actors from eligibility. ibid 35-36.

87 World Bank, "Bank Directive: Guidelines on Preventing Fraud and Corruption in Projects Financed by IBRD Loans and IDA Credits and Grants" (rev 1 July 2016).

88 World Bank, "Procurement Regulations for IPF Borrowers, Procurement in Investment Project Financing, Goods, Works, Non-Consulting and Consulting Services" (rev November 2017) 11 \& 69-71 (Annex IV).

89 See, e.g., World Bank, "Standard Procurement Document, Request for Bids—Goods (Two Envelope Bidding Process)" (October 2017) 8, Instruction to Bidders 3.1.

9o The Bank sanctions system does not, however, require prior notice in order to have jurisdiction over a party. World Bank Group Legal Vice Presidency, "Advisory Opinion on Certain Issues Arising in Connection with Recent Sanctions Cases, No. 2010/1" (15 November 2010) 7-8.

$91 \quad$ Ibid 9-10. 
INT, which is responsible for investigating allegations of sanctionable practices in WBG-financed projects, assesses every allegation that it receives. Complaints that fall outside of INT's jurisdiction are referred to other areas of the WBG, as appropriate.

INT decides whether to launch a full investigation by applying a set of case selection criteria, which include the status of the project and contract at issue, and the risk to the project (for example, the amount of funds involved). If INT elects not to investigate a case, INT works, where appropriate, with WBG operational staff to address the issues raised through other corrective measures, such as taking procurement or project support actions.

In conducting its investigations, INT is guided by the International Financial Institutions' Principles and Guidelines for Investigations. ${ }^{92}$ If, after investigation, INT believes it has uncovered sufficient evidence that a firm or individual has engaged in one or more sanctionable practices, it provides the firm or individual with that evidence and provides an opportunity to respond. In doing so, INT investigations apply a "more likely than not" standard of proof. $^{93}$ If INT finds their explanation insufficient, INT may commence formal proceedings against the firm or individual by submitting a "Statement of Accusations and Evidence" to the Bank's Suspension and Debarment Officer (the SDO $)^{94}$ or, if the case relates to IFC or MIGA, to the relevant Evaluation Officer. ${ }^{95}$ This is the first tier of the WBG's two-tiered adjudicative sanctions process.

$92 \quad$ IFI Task Force (n 35) attachments 4-8.

93 INT, 2017 Annual Update (n 73), p. 24.

94 "World Bank Sanctions Procedures" (n 73) s III(A)(3.01). INT also can file a Request for Temporary Suspension in cases where INT's investigation is ongoing, but INT already believes it has sufficient evidence to conclude that, more likely than not, a party has engaged in a sanctionable practice. If OSD agrees that the evidence presented supports the finding of a sanctionable practice and that the alleged sanctionable practice would warrant a minimum debarment period of two years if it had been included in a Statement of Accusations and Evidence, it can temporarily suspend the Respondent for up to one year, during which INT must continue and complete its investigation. Thereafter, INT must either file a full Statement of Accusations and Evidence against the Respondent, or the temporary suspension expires. ibid s III(A)(2).

95 For more information on the sanctions procedures for IFC and MIGA, see International Financial Corporation, "Sanctionable Practices: Overview Sanctions Process" <www.ifc. org/wps/wcm/connect/Topics_Ext_Content/IFC_External_Corporate_Site/AC_Home/ Sanctionable_Practices/> accessed 19 January 2018 and World Bank, "MigA Sanctions Procedures" <www.miga.org/Documents/MIGA-Sanctions-Proceduresı.pdf> accessed 19 January 2018 , respectively. 
The SDo is tasked with evaluating whether INT's allegations, as presented, are supported by "sufficient evidence,"96 meaning that it is "more likely than not" that the alleged misconduct occurred. ${ }^{97}$

If the SDo determines that there is insufficient evidence to support one or more of the accusations, the case is referred back to INT for the removal of the unsupported accusation(s) or, at INT's discretion, for further investigation. ${ }^{98}$

In cases where the SDo determines that there is sufficient evidence for each of the accusations presented, the SDo issues a "Notice of Sanctions Proceedings" (Notice) to the accused firm(s) or individual(s) — called the "Respondent" - giving the Respondent the opportunity to review and respond to the case against it. In this Notice, the sDo also recommends a sanction, which is imposed if the Respondent chooses not to contest the case. ${ }^{99}$

The appropriate sanction is determined by considering aggravating and mitigating factors that are set out in the Bank's Sanctioning Guidelines. ${ }^{100} \mathrm{Ag}$ gravating factors include the severity of the misconduct, the harm caused, interference with INT's investigation and a history of adjudicated misconduct. Mitigating factors include the Respondent's minor role in the misconduct, evidence of voluntary corrective action and cooperation with the investigation. ${ }^{101}$

Any Respondent that the sDo recommends debarring for six months or more is "temporarily suspended."102 This means that, from the moment the Notice is issued, that Respondent is no longer eligible to be awarded new Bankfinanced contracts or otherwise participate in new Bank-financed activities. ${ }^{103}$ This is done to protect Bank-financed operations pending the outcome of sanctions proceedings. It also removes incentives to prolong sanctions proceedings. Information about temporary suspensions is made available to WBG staff and member country counterparts, but is not made public.

Respondents are then afforded a series of opportunities to contest the accusations and/or the recommended sanction. First, within 30 days of receiving

\footnotetext{
96 "World Bank Sanctions Procedures" (n 73) s II (u).

97 Ibid s III(A)(8.02)(b)(i).

98 World Bank, "The World Bank Office of Suspension and Debarment Report on Functions, Data and Lessons Learned 2007-2015" (2nd edn, 2015) (“OsD Report 2007-2015") 12.

99 "World Bank Sanctions Procedures" (n 73) s iII(A)(4).

$100 \quad$ Ibid S III (A)(9.02).

101 Ibid s III(A)(9.02)(e).

102 Ibid s III (A)(4.02)(a).

103 Temporary suspension has the same effect as debarment, which is discussed further below.
} 
a Notice of Sanctions Proceedings, a Respondent may submit a written explanation to the SDO. This explanation may present arguments and evidence why the case should be withdrawn, or the recommended sanction revised. The SDO issues a formal, written review of all explanations. ${ }^{104}$

If the SDO does not withdraw the case, the Respondent may contest it before the second tier of the sanctions process, the WBG Sanctions Board, by submitting a Response, which is due within go days of receipt of a Notice of Sanctions Proceedings. ${ }^{105}$ The Sanctions Board has seven members, all external to the WBG, supported by a permanent Secretariat. Under its statute, the Sanctions Board is charged with reviewing and taking decisions in sanctions cases fairly, impartially, diligently, independently from any other entity and solely on the merits of the case. ${ }^{106}$

If a Respondent does not contest the case to the Sanctions Board, the SDO imposes its recommended sanction, and issues a Notice of Uncontested Sanctions Proceedings, which is posted on the Bank's public website. ${ }^{107}$ Historically, about two-thirds of Respondents have chosen not to contest their cases to the Sanctions Board. 108

If a Respondent submits a Response to the Sanctions Board, INT, in turn, may also submit a Reply within 30 days after receipt of the Response. ${ }^{109}$ The Sanctions Board then reviews the case on a de novo basis, and is not bound by the SDo's findings or recommended sanction(s). The Sanctions Board may hold a hearing at the request of INT, the Respondent or the Sanctions Board Chair. The Sanctions Board then issues a written, fully-reasoned decision resolving the case, which is posted on the Bank's public website. ${ }^{110}$ Sanctions Board decisions are final, with no opportunity for further appeal. ${ }^{111}$

\footnotetext{
104 "World Bank Sanctions Procedures" (n 73) ss III(A)(2.02-2.04), III(A)(4.02).

105 Ibid s III (A)(5.01)(a).

106 World Bank Group, "wв Policy: Statute of the Sanctions Board" ("Statute of the Sanctions Board") (issued 18 October 2016) ss III(A)(1) \& III(B)(1)-(5).

107 World Bank, "Suspension and Debarment Officer Determinations in Uncontested Proceedings" <web.worldbank.org/WBSITE/EXTERNAL/EXTABOUTUS/ORGANIZATION/ ORGUNITS/EXTOFFEVASUS/o,,contentMDK:22911816 menuPK:7926949 pagePK:64168 445 piPK:64168309 theSitePK:3601046,oo.html> accessed 22 January 2018.

108 “OSD Report 2007-2015” (n 96) 10.

109 "World Bank Sanctions Procedures" (n 73) s III (A)(5.01)(b).

110 ibid ss III(A)(8.01), III(A)(10.01); see World Bank, "Sanctions Board Decisions" <web. worldbank.org/WBSITE/EXTERNAL/EXTABOUTUS/ORGANIZATION/ORGUNITS/ EXTOFFEVASUS/o,,contentMDK:23059612 pagePK:64168445 piPK:64168309 theSite PK:3601046,oo.html> accessed 19 January 2018.

111 "World Bank Sanctions Procedures" (n 73) s III(A)(8.03). The Sanctions Board has, however, ruled that it will consider requests for reconsideration of its decisions in narrowly
} 


\section{Overview of Potential Sanctions and Integrity Compliance Conditions}

There are five potential sanctions: debarment, debarment with conditional release, conditional non-debarment, restitution and reprimand:

- Debarment renders an entity ineligible, either indefinitely or for a stated period, to be awarded or benefit from a new Bank-financed contract, be a nominated sub-contractor or supplier in a Bank-financed contract, receive the proceeds of Bank financing or otherwise participate in the preparation or implementation of a Bank-financed project. Such ineligibility also applies to IFC, MIGA and Bank Guarantee and Carbon Finance projects. ${ }^{112}$ Debarment is only prospective and does not result in the cancellation of contracts under execution, although it can prevent contract amendments or extensions if they are viewed as constituting new or additional work.

- Debarment with conditional release has the same effect as fixed-term debarment, but ends only if the entity fulfills stated remedial, preventive or other conditions for release from sanction. ${ }^{113}$

- Conditional non-debarment permits an entity to retain its eligibility to participate in Bank-financed projects and activities, and seek and receive Bankfinanced contracts, but only if it fulfills specified remedial and preventive conditions. ${ }^{114}$

- Restitution requires the entity to make financial or other restitution to the affected WB G Borrower or some other entity. ${ }^{115}$

- A Reprimand comes in the form of a letter admonishing the entity for its misconduct. ${ }^{116}$

The default or "baseline" sanction is debarment with conditional release. This sanction, along with conditional non-debarment, provides an opportunity for a sanctioned entity to work with the WBG's Integrity Compliance Office (ICO). Under these conditions, an entity will be released and therefore exit from debarment only after having met the conditions specified in the relevant sanctioning document. In most cases involving firms, the integrity compliance conditions to be met include requiring the firm to demonstrate that it has implemented an integrity compliance program that is consistent with

defined and exceptional circumstances. See, for example, Sanctions Board Decision No 107 (11 January 2018) 2 para 4.

112 "World Bank Sanctions Procedures" (n 73) s III(A)(9.01)(c).

113 Ibid s III (A) (9.01)(d).

$114 \operatorname{Ibid} \mathrm{s}$ III (A)(9.01)(b).

115 Ibid S III (A)(9.01)(e).

$116 \operatorname{Ibid} \mathrm{s}$ III $(\mathrm{A})(9.01)(\mathrm{a})$. 
the principles set out in the WвG's public Integrity Compliance Guidelines. ${ }^{117}$ The WвG Integrity Compliance Officer evaluates and ultimately determines whether entities have fulfilled the conditions for their release from sanction. ${ }^{118}$

Integrity compliance is taking on a more prominent and more preventive role in the sanctions process. Like other development organizations, the WBG is increasingly leveraging private finance and private sector engagement to meet the sustainable development goals. A greater private sector role presents a new set of risks - and opportunities - in the Bank's fiduciary work.

In that regard, the ICO is increasingly seeking opportunities, such as through workshops, for the WBG to promote the voluntary adoption of integrity compliance principles and programs among private sector entities simply as a good business practice rather than only in response to a WBG sanction. Such an expansion of the WBG's integrity compliance work, beyond sanctions, could further augment preventive measures aimed at enhancing the proper use of funds in WBG-financed projects. The ICO also is leveraging the experience of previously sanctioned firms. For example, the ICO has developed a mentoring program whereby firms that have been released from sanction after meeting their integrity compliance conditions are paired with currently sanctioned firms to provide guidance and feedback on the sanctioned firms' integrity compliance program enhancement efforts. ${ }^{119}$ In addition, released firms more broadly tend to publicly promote integrity compliance because they want to ensure that there is a level playing field that disfavors corrupt actors and rewards their integrity compliance program effort and investment.

Negotiated Resoluction Agreements

Negotiated Resolution Agreements (NRAs or Settlements) incentivize proactive remediation by firms (what some would call "consideration for cooperation") and provide a streamlined alternative to the contested adjudication of sanctions cases. A Settlement provides for the resolution of an investigation or sanctions case through a mutually agreed settlement between the Respondent and INT. A Settlement may be entered into at any point prior to or during sanctions proceedings, until the SDO issues a Notice of Uncontested Sanctions

117 World Bank, "Summary of World Bank Group Integrity Compliance Guidelines" <http:// siteresources.worldbank.org/INTDOII/Resources/IntegrityComplianceGuidelines_2_1_11 web.pdf $>$ accessed 19 January 2018.

118 "World Bank Sanctions Procedures" (n 73) s III(A)(9.03)(d).

119 INT, “2017 Annual Update” (n 73) 20-21. 
Proceedings, or the Sanctions Board issues a decision. ${ }^{120}$ INT provides all Respondents with an opportunity to resolve their case through a Settlement.

INT negotiates a draft Settlement with the Respondent. The negotiated Settlement is cleared by the Bank's General Counsel for legal adequacy, and then submitted to the SDo to confirm that: (i) the Respondent entered into the Settlement freely, fully informed of its terms and without any form of duress; and (ii) the Settlement's terms do not manifestly violate the Bank's Sanctions Procedures or Sanctioning Guidelines. ${ }^{121}$

Respondents benefit from Settlements because they provide for certainty of outcome and provide for a lesser sanction than if the case were contested, as Settlements include mitigating credit for cooperation and admission of wrongdoing. ${ }^{122}$ The Bank benefits from the Respondent's commitments to cooperate with INT, provide INT with information that INT can use in other cases and either implement or improve its integrity compliance program. Both sides gain clear procedural benefits from the abbreviated process: A Settlement permits a speedier resolution of matters and requires a smaller investment of resources.

Lessons Learned

From the experience of implementing the WBG's sanctions system, in particular the two-tiered system as it has existed since it began to operate in 2007, seven lessons can be drawn. ${ }^{123}$

The first lesson is that independence is crucial for due process. The measure of a truly independent sanctions system is the ability to investigate, adjudicate and sanction without internal or external interference-in other words, to resist pressure to either investigate or sanction where there is insufficient evidence, or to not investigate or sanction when a party is high-profile or powerful.

A second lesson is the importance of transparency in procedures, as well as case outcomes and the reasons for them. There are always limits to the

120 "World Bank Sanctions Procedures" (n 73) s III(B)(2).

121 See World Bank, "World Bank Group Settlements: How Negotiated Resolution Agreements Fit Within the World Bank Group's Sanctions System" <http://siteresources .worldbank.org/INTDOII/Resources/NoteOnSettlement Process.pdf $>$ accessed 20 January 2018.

122 World Bank, "World Bank Group Sanctioning Guidelines" (1 January 2011) <http://sitere sources.worldbank.org/EXTOFFEVASUS/Resources/WorldBankSanctioningGuidelines. pdf $>$ accessed 19 January 2018.

123 See "OsD Report 2007-2015" (n 97) 18-19. 
disclosure of information; some information needs to be kept confidentialfor instance the identity of confidential witnesses. However, experience and common sense tell us that meaningful public disclosure can help to confer legitimacy on the system and promote its deterrent effect. In the WBG's system, the full text of Sanctions Board decisions, ${ }^{124}$ as well as reports on OSD decisions in uncontested cases, ${ }^{125}$ are posted online. The full text of the legal framework for the system is also publicly available, ${ }^{126}$ as are annual reports, information notes and advisory opinions. ${ }^{127}$

A third lesson is the importance of written procedures. These include carefully drafted policies; clear terms of reference setting out the roles and responsibilities of all the actors in the system; written internal procedures; and documented decision-making. Generating these procedures well in advance, before a live matter presents itself, is something the Bank has found very useful. Internal processes are important. Documenting one's thinking and thought process that lead to decisions helps ensure equal treatment of all Respondents. Documentation promotes internal discipline and quality and allows an examination of decisions over time.

A fourth lesson is to create appropriate vehicles for resolving new policy issues, which arise inevitably in any system. When they do arise, it is crucial to know in advance who the decision maker will be for vetting and resolving them. At the Bank, this role is played by the Sanctions Advisory Committee. ${ }^{128}$ A fifth lesson is the importance of having a range of appropriate options and tools for proportionate case outcomes. As outlined in this article, the WBG has a range of sanctions outcomes available, as well as a range of process options, including settlements, uncontested cases and contested cases. These tools

124 World Bank, "Sanctions Board Decisions" <http://web.worldbank.org/WBSITE/EXTER NAL/EXTABOUTUS/ORGANIZATION/ORGUNITS/EXTOFFEVASUS/o,,contentMDK:230 59612 pagePK:64168445 piPK:64168309 theSitePK:36o1046,oo.html> accessed 19 January 2018.

125 "Suspension and Debarment Officer Determinations in Uncontested Proceedings" (n 106).

126 See World Bank, "Procedures and Other Key Documents" <http://web.worldbank.org/ WBSITE/EXTERNAL/EXTABOUTUS/ORGANIZATION/ORGUNITS/EXTOFFEVASUS/o ,contentMDK:21299248 menuPK:3726884 pagePK:64168445 piPK:64168309 theSite PK:3601046,oo.html> accessed 22 January 2018.

127 See World Bank, "Publications" <http://www.worldbank.org/en/about/unit/integrity -vice-presidency/publications> accessed 22 January 2018.

128 See World Bank, "Bank Directive: Sanctions for Fraud and Corruption in Bank-Financed Projects" (effective 1 July 2016) <http://siteresources.worldbank.org/EXTOFFEVASUS/ Resources/3601045-1377105390925/Directive_Bank_Directive_Sanctions_for_Fraud_and _Corruption_in_Bank_Financed_Projects(6.28.2016).pdf> accessed 21 January 2018. 
were developed with an emphasis on the simplification of procedures and on remediation and prevention. They also provide the flexibility required to identify and apply sanctions that best "fit" the sanctionable conduct at issue. ${ }^{129}$

A sixth lesson is that data matters. All international organizations now understand the importance of data and data analytics. IF Is may be able to attain significant preventive gains by comparing known fraud and corruption risk patterns against present and future project designs, mining e-procurement tender data for red flags of collusion among bidders or utilizing due diligence information to identify shell companies or entities known to be corruption risks.

A seventh and final lesson relates to the importance of measuring timelines. These aid accountability both within the system and with external entities. They also are vital for ensuring - and tracking - the efficiency of all the sanctions actors. A good case management system is essential. What gets measured gets done. Both INT and OSD provide extensive, public data on investigation and sanction case types, progress and outcomes, as well as preventive and integrity compliance activities. ${ }^{130}$

129 "World Bank Sanctions Procedures" (n 73) s ini(A)(9.02).

130 See, for example, InT, “2017 Annual Update” (n 73) 23-35; “OsD Report 2007-2015” (n 96). 